\title{
DYSKUSJE W SPOŁECZEŃSTWIE LITEWSKIM O PRZYSZŁOŚCI WILNA ORAZ KWESTIE NAWIĄZANIA STOSUNKÓW DYPLOMAT YCZNYCH Z POLSKĄ W 1934 R.
}

W latach międzywojennych Republika Litewska do marca 1938 roku nie utrzymywała $z$ Polską stosunków dyplomatycznych, jak też kulturalnych i gospodarczych. "Nieoficjalnie” prowadzono handel z Polską przez kraje trzecie. Litwa sprowadzała polską sól, cukier, wyroby włókiennicze, węgiel kamienny, metale i niektóre wyroby metalowe. Wszystkie rządy i partie Litwy nie uznawały włączenia Wilna i Wileńszczyzny do Polski, konsekwentnie traktowano te tereny jako okupowane przez Polskę. Sprawa wileńska była niejednokrotnie rozpatrywana na płaszczyźnie międzynarodowej, szczególnie na forum Ligi Narodów w Genewie. Litwa uzasadniała swoje prawa do Wilna i Wileńszczyzny argumentami historycznymi i etnograficznymi oraz traktatem pokojowym z Rosją Radziecką z 12 lipca 1920 roku. W społeczeństwie litewskim powstawał stopniowo „kult Wilna”. W tworzeniu tego „kultu” wielką rolę odegrała organizacja „Związek Wyzwolenia Wilna", która korzystała z poparcia władz litewskich, zwłaszcza od grudnia 1926 roku, kiedy na Litwie skończył się okres parlamentaryzmu.

Po wojskowym zamachu stanu władzę na Litwie zdobyli narodowcy. Ich przywódca i założyciel stronnictwa A. Smetona został prezydentem Republiki, natomiast premierem - inny lider narodowców A. Woldemaras. Od jesieni 1929 roku po odsunięciu Woldemarasa od władzy, A. Smetona stał się praktycznie nieograniczonym w swojej władzy przywódcą państwa litewskiego. Umiarkowanie autorytarna władza prezydenta A. Smetony zapewniła stabilność polityczną, porządek oraz stosunkowo szybki rozwój gospodarczy i kulturalny. 
Natomiast w polityce zewnętrznej Litwa miała dwa bolesne problemy: Wilna i Kłajpedy. W wyniku traktatu wersalskiego Niemcy utraciły Kraj Kłajpedzki na rzecz Litwy, do której został on - jako autonomiczna część Republiki - przyłączony w 1923 roku. Niemcy jednak stale wtrącały się w sprawy Kraju Kłajpedzkiego i wywierały nacisk na Litwę. Od początku 1933 roku nacisk ten stał się szczególnie silny.

Konflikt z Niemcami o Kłajpedę wskazywał na potrzebę uregulowania w jakiś sposób sporu z Polską. Premier Woldemaras bagatelizował jednak niebezpieczeństwo niemieckie i nie godził się na kompromis w sprawie normalizacji stosunków z Polską. Dopiero po usunięciu Woldemarasa od steru władzy rozpoczęła się w tej sprawie dyskusja. Pierwszą jaskółką stały się artykuły opublikowane w końcu 1930 roku w dzienniku litewskich ludowców „Lietuvos zinios”. Dyskusja z różnym napięciem trwała w latach 1930-1933². Kulminacja nastąpiła w 1934 roku.

Nie była to kwestia przypadku: sytuacja międzynarodowa Litwy znacznie się pogorszyła. Władze nazistowskich Niemiec nie ukrywały swoich agresywnych zamiarów w stosunku do Litwy. W Kraju Kłajpedzkim, korzystając z jego autonomii, powstawały masowe organizacje hitlerowskie. Szykowały one przewrót w Kraju Kłajpedzkim, jego oderwanie od Litwy i przyłączenie do Trzeciej Rzeszy. Z drugiej strony Polska w 1932 roku zawarła pakt o nieagresji ze Związkiem Radzieckim, a w styczniu 1934 roku została podpisana polsko-niemiecka deklaracja o niestosowaniu przemocy. Oba traktaty wzmocniły, jak wtedy powszechnie uważano, bezpieczeństwo i pozycję międzynarodową Polski.

Konfrontacja z Polską pogorszyła sytuację Litwy w obliczu zagrożenia niemieckiego, przeszkadzała też utworzeniu tak zwanej Ententy Bałtyckiej, do której miały należeć: Litwa, Łotwa oraz Estonia. Stawiany przez dyplomatów litewskich warunek, aby Łotwa i Estonia poparły Litwę w kwestii wileńskiej stawał się coraz mniej realistyczny. Problem Bałtyckiej Ententy albo sojuszu był żywo omawiany w prasie i dyskutowany w społeczeństwie litewskim.

2 maja 1934 roku na Uniwersytecie Kowieńskim odbyła się publiczna dyskusja nt. „Sojusz Bałtycki i sprawa Wilna”. Przed licznym gronem zebranych studentów i inteligencji wystąpili profesorowie uniwersýtetu oraz znani działacze społeczni. Największe wrażenie wywarło wystąpienie wybitnego naukowca, działacza socjaldemokracji litewskiej, byłego ministra oświaty

1 Szerzej: R. Żepkaite, Diplomatija imperializmo tarnyboje. Lietuvos ir Lenkijos santykiai 1919-1939 m., Vilnius 1980, s. 230-233. 
i byłego rektora Uniwersytetu - profesora Wincenta Czepińskiego. Na początku W. Czepiński (V. Čepinskis) oświadczył, że za największego wroga narodu litewskiego należy uważać Niemcy, a nie Rosję czy Polskę. Problem Wilna długo wykorzystywały na Litwie różne siły polityczne w swoich partyjnych interesach, co źle wpływało na społeczeństwo i stworzyło wręcz sytuację „psychopatologiczną”. Dalej profesor stwierdził: „My z Wilna nie rezygnujemy, lecz trzeba szukać drogi, jak szybciej, łatwiej i lepiej sprawę rozwiązać. Nie możemy dłużej stawiać sprawy w taki sposób: „Oddajcie Wilno, a potem będziemy pertraktować... Żeby pertraktować, trzeba nawiązać stosunki" 2 .

Czepiński zarzucił litewskiej inteligencji, że w ciągu ostatnich dziesięciu lat mówiła o sprawie Wilna takie bzdury, jakich on nigdy nie słyszał od ludzi prostych, od chłopów, i konkludował: „Pamiętajmy, jeżeli kiedyś jakikolwiek wróg zniszczy Polskę, Litwa też się nie ostanie". Zwrócił również uwagę, że są także inni pretendenci do zajęcia Wilna; swoje roszczenia stale podkreślają Białorusini. Polacy, jak i Litwini, zainteresowani są w tym, żeby Wileńszczyzna nie dostała się w objęcia Wschodu (tj. stalinowskiego ZSRR - A.K.): „Koniecznie trzeba z Polską pertraktować... gdy zaistniała potrzeba, gdy wymagały tego interesy państwa, to Gedymin i Witold nie obawiali się zawrzeć przymierza $z$ odwiecznymi wrogami".

W ferworze polemicznym profesor wysunął mocno wątpliwą tezę, której później uchwycili się wszyscy jego krytycy, mianowicie: „Gdybyśmy teraz odzyskali Wilno, upadlibyśmy jako państwo i naród. Dlatego jest wielką łaską Pana Boga, że teraz jeszcze Wilno nie należy do nas" 3 .

Jednakże tego dnia, podczas dyskusji w sali Uniwersytetu nikt z zabierających głos nie oponował Czepińskiemu, natomiast w różnych sprawach uzyskał on poparcie. Znany litewski uczony, znawca zagadnień geopolityki, działacz chrześcijańskiej demokracji profesor K. Paksztas (Pakštas) podkreślił, że sprawa Kłajpedy ma doniosłe znaczenie dla Litwy i w ostrych słowach potępił zaborcze zakusy niemieckie. Zauważył on, że dla Łotwy oraz Estonii polskie zagrożenie nie istnieje, ani Łotwa ani Estonia dla Litwy „sprzymierzeńcami w sprawie Wilna nie były i nie będą". Sprawa Wilna nie powinna przesłaniać innych problemów Litwy, przede wszystkim kwestii Kłajpedzkiej" 4 .

\footnotetext{
2 „Rytas”, 4.V.1934, nr 101.

3 Tamże.

4 Tamże.
} 
Dyskusja na Uniwersytecie wywołała, jak można było oczekiwać, szeroki rezonans w społeczeństwie i w prasie. Namiętności spotęgowało wystąpienie w dzienniku „Rytas” jednego z liderów chrześcijańskiej demokracji, byłego premiera, kilkakrotnie w przeszłości i przyszłości (1939 r.) Leona Bistras'a całkowicie popierające wszystkie twierdzenia W. Czepińskiego. W artykule Rozum $w$ polityce pisał on: „W dyskusji po raz pierwszy od zagarnięcia Wilna litewscy działacze społeczni otwarcie powiedzieli to, co w rzeczywistości myśleli już od dawna, co uważali za słuszne, to co jest jedynie praktyczne, politycznie rozumne... Co nowego i niezwykłego w tej dyskusji? Nic, z wyjątkiem otwartości" 5 .

L. Bistras twierdził, że wszyscy mówcy zgadzali się, między innymi, z poglądem, że Litwa na początku powinna wznowić stosunki z Polską i dopiero potem szukać rozwiązania problemu Wilna, możliwego do przyjęcia dla obu stron. Nikt na zebraniu nie protestowal, kiedy W. Czepiński stwierdził ,jeżeli my odzyskamy Wilno teraz, to zginiemy jako naród i jako państwo". Autor artykułu jakby ostentacyjnie oświadczył, że Czepiński „głośno wszystkim powiedzial, to co każdy świadomy Litwin już od dawna miał w sercu".

Nieprzychylnie na zebranie na Uniwersytecie zareagował dziennik rządowy "Lietuvos aidas” artykułem Więcej powagi, lecz krytyka była stosunkowo umiarkowana ${ }^{6}$. Ostry wydźwięk miał drugi, obszerny artykuł „Lietuvos aidas" pod tytułem Niedopuszczalne wyskoki ${ }^{7}$. Jednak i tym razem była to reakcja władzy nie tyle na dyskusję na Uniwersytecie, co na rozgłos, który jej (a szczególnie poglądom W. Czepińskiego) nadał dziennik „Rytas” piórem L. Bistras'a. Poglądy W. Czepińskiego „Lietuvos aidas” scharakteryzował jako jaskrawy przykład poglądów psychopatologicznych „...o których profesor mówił w nawiązaniu do sprawy Wilna". Takie poglądy są absurdem, ponieważ jeżeli Litwa rzeczywiście upadłaby, będąc $\mathrm{w}$ posiadaniu Wilna, to, z ironią ciągnął publicysta rządowego dziennika: „Piłsudski z Żeligowskim ocalili naszą niepodległość... Więc nie trzeba ich przeklinać i wymyślać im, lecz powinniśmy im nadać najwyższy order Litwy oraz przyznać tytuł: «patres patriae»...". Jednocześnie podkreślił, że prof. W. Czepiński przynajmniej przyznal, że wyraża swoje osobiste zdanie. Natomiast prof. L. Bistras ośmielił się napisać, że każdy świadomy Litwin już od dawna tak uważa.

5 „Rytas”, 7.V.1934, nr 103.

6 „Lietuvos aidas”, 7.V.1934, nr 103.

7 „Lietuvos aidas”, 11.V.1934, nr 106. 
W zakończeniu artykułu w „Lietuvos aidas” znalazło się zapewnienie, że „postawa litewska w kwestii wileńskiej nie zmieniła się, nie zmieni się i zmienić się nie może. Wilno jest odwieczną stolicą Litwy, naród litewski, dopóki będzie żył, dołoży wszelkich starań, aby odzyskać stolicę i żadni podstarzali profesorowie go od tego nie odwiodą i nie zmienią jego przekonań" 8 . Wyrażał też opinie, że takie rzeczy jak wspomniane zebranie na Uniwersytecie czy artykuł w gazecie "Rytas" są niedopuszczalne. Jednak w całym dość ostrym artykule "Lietuvos aidas" nie było ataków na poglądy polityczne W. Czepińskiego i L. Bistras'a, zarzutów co do ich wcześniejszej działalności politycznej i ministerialnej. A zarzutów - w tym także o przychylność Polsce i Polakom - można było zgłosić pod adresem jednego i drugiego wiele.

Na przykład w 1926 roku W. Czepiński będąc ministrem oświaty Litwy wydał zezwolenie polskim organizacjom na założenie prawie stu prywatnych szkół, był za to ostro krytykowany. Tym razem epizodu z 1926 roku nie wypomniała W. Czepińskiemu nie tylko gazeta rządowa, ale także inne wydawnictwa. Nie odwoływano się do niego też w oświadczeniach oraz rezolucjach licznych zebrań członków takich organizacji jak strzelcy (šauliai), Związek Wyzwolenia Wilna, młodzieży narodowej i innych, które odbyły się w drugiej i trzeciej dekadzie maja. W oświadczeniach i rezolucjach potępiano opinie obu profesorów, lecz nie wyrazicieli tych opinii osobiście. W rezolucji protestacyjnej tzw. zebrania społeczeństwa Kowna wprost pisano:

„1) Potępić opinię wyrażoną przez prof. Czepińskiego 2 maja w sali Uniwersytetu,

2) Potępić przewodnią myśl artykułów Bistras'a postulującą «zawieszenie» rozwiązania sprawy Wilna" 9.

Niewątpliwie niektórzy mówcy na zebraniach ostro potępiali także samych wyrazicieli opinii, zarzucając im „grzechy” przeszłości, ale nie znalazło to odbicia w prasie. Odnosi się to także do wypowiedzi różnych działaczy w litewskich gazetach i czasopismach.

Osobistych ataków na W. Czepińskiego i Bistras'a nie było nawet w tekstach publikowanych przez dwutygodnik Związku Wyzwolenia Wilna "Mūsụ. Vilnius" ( Nasze Wilno") i tygodnik Związku Strzelców (szaulisów) "Trimitas". W tych gazetach zdanie Czepińskiego i Bistras'a określano mianem „dziwnych", „niezrozumiałych", „błędnych".

Znany litewski publicysta, były minister spraw zagranicznych J. Puryckis, który pisał pod pseudonimem Vygandas, w obszernym artykule w „Try-

\footnotetext{
8 Tamże.

9 „Mūsı Vilnius” 1934, nr 10, s.170.
} 
mitas” zaznaczył: „Tak więc wypowiedź prof. Czepińskiego jest błędną pod każdym względem. To nieprzemyślana wypowiedź, można ją tłumaczyć tylko gorączką mityngu; ale o to inny profesor, dr Bistras idealizuje jego wypowiedź jako wyraz największej mądrości. Przypisuje on mityngowi na Uniwersytecie wprost epokowe znaczenie" 10.

Należy zauważyć, że jeżeli nawet nie było to wydarzenie „epokowe”, to w każdym bądź razie duże. Zebranie na Uniwersytecie 2 maja, wypowiedź prof. Czepińskiego i poparcie udzielone mu przez L. Bistras'a przez cały maj było w centrum uwagi litewskiego społeczeństwa i prasy. Praktycznie poza L. Bistras'em, który opublikował dwa artykuły w dzienniku „Rytas", nikt więcej nie poparł bezpośrednio twierdzeń W. Czepińskiego. Prawie wszystkie gazety i czasopisma drukowały zapewnienia, że „świadomi Litwini uważają zupełnie inaczej niż Czepinskis oraz Bistras, a „odzyskanie Wilna leży w żywotnym interesie narodu litewskiego oraz że Republika Litewska dążyła i będzie dążyć do odzyskania Wileńszczyzny, samotnie czy wspierana przez sojuszników". Jednocześnie, jak już wspomnieliśmy, osobiste ataki i potępienie politycznej działalności Bistras'a i Czepińskiego w przeszłości nie miały miejsca.

Może ówczesna prasa litewska była wysoce dżentelmeńska; polemiki prowadzono bez żadnych emocji? Tak nie było. W tym samym 1934 roku niemało sporów wy'wołały wypowiedzi byłego premiera A. Woldemaras'a i jego artykuły w prasie Niemiec hitlerowskich, w których zachęcał do ustępstw wobec Niemiec w sprawie Kraju Kłajpedzkiego i oskarżał rząd litewski, że to właśnie jego polityka wywołuje napięcie. Polemika z Wolemaras'em nie była zbyt dżentelmeńska. W kwietniu 1934 roku, w przeznaczonym dla inteligencji tygodniku "Naujoji romuva”, Voldemaras był nazwany przyjacielem nazistowskich dygnitarzy Ericha Kocha i Rudolfa Hessa i porównany $z \mathrm{He}-$ rostratesem z Efezu, który pragnąc zdobyć sławę podpalił słynną świątynię Artemidy, oraz z cesarzem rzymskim Neronem, który rozkazał podpalić Wieczne Miasto ${ }^{11}$. Surowo wypomniano Woldemaras'owi wszystkie jego jako polityka - „grzechy”, w tym także to, że nie chciał lub nie potrafił w 1918 roku, kiedy był premierem, stworzyć litewskiego wojska. To dlatego bolszewicka Armia Czerwona bez trudu zajęła Wilno, w wyniku czego stolica Litwy ostatecznie przypadła Polsce ${ }^{12}$.

\footnotetext{
10 „Trimitas” 1934, nr 20, s. 386.

11 „Naujoji romuva” 1934, nr 171, s. 322.

12 „Trimitas” 1934, nr 32, s. 628-629.
} 
Dla porównania należy przytoczyć dłuższy cytat z miesięcznika narodowców "Vairas", w którym była mowa o wypowiedziach Czepińskiego i Bistras'a. Krytykując ich poglądy w sprawie Wilna wybitny publicysta Vygandas (J. Pruryckis) zaznaczył: „Nie nazwę prof'esorów Czepińskiego i Bistras'a ani zaprzedańcami, ani zdrajcami, ani dezerterami, jak to się czasem u nas czyni z ludźmi myślącymi inaczej, ani trochę nie wątpię w szczerość ich intencji. Mylą się - i nic więcej. Jednakże to bardzo duże pomyłki" ${ }^{13}$. Oczywista jest więc różnica w wartościowaniu postaw Czepińskiego i Bistras'a oraz Woldemaras'a.

Należy podkreślić, że Czepiński i Bistras byli najbardziej krytykowani w prasie nie za postulat nawiązania stosunków z Polską i nawet nie za ocenę dotychczasowej polityki Litwy w sprawie Wilna jako „psychopatologicznej”. Działacze społeczni o różnych orientacjach i publicyści najostrzej polemizowali z tezą, która rzeczywiście była nie do obronienia, a mianowicie: „jeżeli odzyskamy Wilno teraz, to zginiemy jako naród, jako państwo". Tę tezę surowo potępili, wyśmiali w swoich listach liczni czytelnicy gazet, członkowie Związku Strzelców (szaulisów) oraz Związku Wyzwolenia Wilna, jak też Litwini z Wileńszczyzny.

Krytykowali ją także umiarkowani działacze społeczni. Wybitny litewski ekonomista, były minister finansów w gabinecie, który był obalony w drodze wojskowego zamachu stanu w końcu 1926 roku, ludowiec A. Rimka w dzienniku „Lietuvos žinios” pisał, że nawet Polacy „od których słyszeliśmy najróżniejsze argumenty, dotychczas jeszcze nie ośmielili się twierdzić, że Wilno nas zgubi" " ${ }^{4}$. A. Rimka zaznaczył, że walka o Wilno może stać się dla Litwy beznadziejna $z$ powodów politycznych czy militarnych, ale nie $z$ gospodarczych albo finansowych. Wkrótce A. Rimka w tymże dzienniku opublikował dwa obszerne artykuły, w których w sposób dość uzasadniony udowadniał, że sytuacja gospodarcza Wilna i Wileńszczyzny nie jest katastroficzna i nie byłoby dla Litwy ciężarem nie do uniesienia, gdyby znalazły się w jej granicach ${ }^{15}$.

Powstaje więc wrażenie, że koncentracja uwagi na tej właśnie kwestii oznaczała, iż znaczna część społeczeństwa i rząd nie odrzucały idei rewizji polityki litewskiej w sprawie Wilna i nawiązania stosunków dyplomatycznych z Polską „z założenia”. Nie przeczy takiemu wnioskowi również powściągliwa postawa prezydenta Republiki.

13 „Vairas” 1934, t. XI, nr 6, s. 240.

14 „Lietuvos żinios”, 14.V.1934, nr 108.

15 „Lietuvos żinios”, 29.V.1934, nr 120; 30.V.1934, nr 121. 
A. Smetona po raz pierwszy pośrednio zabrał głos w dyskusji 18 maja w przemówieniu w kowieńskim klubie oficerów. Prezydent zwięźle zaznaczył, że sytuacja międzynarodowa jest trudna i groźna dla Litwy, jednak „takie czy inne powątpiewania w pomyślną przyszłość naszego kraju nie powinny mieć miejsca. Nie wyrzekniemy się Wileńszczyzny" 16.

Szerzej i bezpośrednio na ten emocjonujący temat A. Smetona wypowiedział się 26 maja na corocznym zjeździe litewskich kombatantów-ochotników 1918-1920 r. Przemówienie Prezydenta odzwierciedlało tak jego paternalistyczną i autorytarną postawę w stosunku do społeczeństwa, jak i właściwą jemu powściągliwość w ocenie spraw i ludzi: „Nie należy obciążać władzy wszystkimi zadaniami. Niech wszyscy współpracują z nią harmonijnie, nie oponując. Wszyscy powinni władzy pomagać. Ale niektórzy, chcąc jej pomóc idą zbyt daleko w politykę, a takie wybryki szkodzą kierowanej przez władze działalności państwa. Czasem nieprzemyślana i nieostrożna wypowiedź człowieka o uznanym autorytecie jest podchwytywana, nawet deformowana i użyta na niekorzyść Litwy. Należy być ostrożnym" ${ }^{17}$.

Tak więc Czepińskiego i Bistras'a bezpośrednio nie wspomniano i nie potępiano, a tylko stanowczo doradzono "ludziom o uznanym autorytecie", aby „byli ostrożniejsi”. W sprawie Wilna Prezydent potwierdził stały kierunek: Litwa dąży do odzyskania Wilna i Wileńszczyzny i nie odstąpi ich obcym.

3 czerwca 1934 roku Prezydent wygłosił jeszcze jedno przemówienie - w Dubingiai, całkiem niedaleko polskiej granicy, którą Litwa uważała za tymczasową tzw. linię demarkacyjną. W tym przemówieniu A. Smetona nawet nie wspomniał o dyskusji w społeczeństwie litewskim w sprawie Wilna oraz stosunków z Polską, jednak był bardzo stanowczy w kwestii przynależności Wilna i Wileńszczyzny do Litwy. Zapewniał słuchaczy, że „zaklęta granica, oddzielająca nas od Wilna, nie jest wieczna. Przyjdzie czas, gdy podamy rękę naszym braciom w drodze do Wilna i znowu będziecie mogli swobodnie nawiedzać Ostrą Bramę, zdążając tam starymi drogami... Cały kraj Wileński musi znaleźć się w granicach Litwy. I tak będzie" 18 .

Więcej w 1934 roku w sprawie Wilna Prezydent nie wypowiadal się bardziej wyczerpująco; poza może - jeżeli tak można powiedzieć - rytualnymi aluzjami. Autorytarna władza A. Smetony znalazła się przed groźbą

16 „Lietuvos aidas”, 19.V.1934, nr 113.

17 „Lietuvos aidas”, 30.V.1934, nr 121.

18 „Lietuvos aidas”, 5.VI.1934, nr 125. 
upadku, zaledwie w trzy dni po przemówieniu w Dubingach, kiedy wczesnym rankiem 7 czerwca grupa oficerów wyprowadziła na ulice Kowna kilka oddziałów i czołgi. Celem demonstracji było wymuszenie na prezydencie nominacji Woldemaras'a na premiera, w miejsce J. Tūbelis'a. Jednym z powodów niezadowolenia wśród oficerów (chociaż nie najważniejszym) było podejrzenie, że ówczesna władza gotowa jest do zmiany dotychczasowej postawy w sprawie Wilna.

Przewrót się nie powiódł ze względu na niezdecydowanie dowódców i brak koordynacji w działaniach poszczególnych oddziałów. Prezydent odrzucił przedstawione mu żądanie nominacji Woldemaras'a, rozumiejąc doskonale, że po powrocie do władzy postarałby się on przede wszystkim usunąć A. Smetonę. Oficerowie nie przewidzieli ewentualności odrzucenia przez Prezydenta ich żądań, nie byli przygotowani na aresztowanie Smetony, a nie odważyli się zaimprowizować takiego działania. Oddziały wróciły do koszar, oficerowie nie stawiali oporu przy aresztowaniu. Aresztowano też Woldemaras'a, który nie skorzystał z możliwości ucieczki do Niemiec.

Władza rozpoczęła czystki w wojsku, zwolniono ze służby 60 oficerów, dwudziestu trzech $z$ nich zdegradowano do szeregowców. Trzej oficerowie, wśród nich szef Sztabu Generalnego generał P. Kubiliunas, zostali skazani na śmierć, jednak wyrok Prezydent zmienił na karę dożywotniego więzienia. Skazano też Woldemaras'a na 12 lat więzienia ${ }^{19}$.

Próba przewrotu była nieudana, ale sam fakt jej istnienia dowodził, że autorytaryzm Smetony napotyka groźne przeszkody nie tylko w polityce zagranicznej, lecz i wewnętrznej. Nie było dowodów na istnienie jakichkolwiek związków między spiskowcami i opozycją demokratyczną, ostatecznie warstwy rządzące nie wysuwały podobnych oskarżeń ani pod adresem oficerów, ani partii opozycyjnych. Strach ma jednak wielkie oczy... zaczęto patrzeć na opozycję jeszcze podejrzliwiej, starając się jednocześnie nie rozdrażniać tych grup społeczeństwa litewskiego i organizacji prorządowych, które były przeciwne jakiejkolwiek zmianie polityki w sprawie Wilna i stosunków z Polską.

Publicysta pisma „Vairas” (Algirdas Daumantas) oskarżył nawet partie opozycji demokratycznej o inspirowanie dyskusji w sprawie Wilna, o próbę skompromitowania rządu narodowców i powrotu do władzy. Pisał on: „Za-

19 A. Woldemaros'owi oraz wszystkim osądzonym oficerom Prezydent Republiki już na początku 1938 roku udzielił amnestii i wyszli oni na wolność. A. Smetona nie chciał przydać im aureoli męczeństwa. 
znaczają się dość wyraźne tendencje, wśród tzw. partii opozycyjnych, aby ciągle skłaniać rząd narodowy do pertraktacji z Polakami, twierdząc, że nawet $z$ Wilna można «czasowo» zrezygnować. Lecz strategia tych partii jest latwa do rozszyfrowania, nawet dla nie-polityka. Niech rząd narodowy na jakichkolwiek warunkach rozpoczyna pertraktacje z Polską, niech według p. Bistras'a sprawę Wilna «zawiesi» - przecież łatwo się domyślić, że taka awanturnicza polityka wkrótce doprowadziłaby do zamieszania $\mathrm{w}$ kraju... może wówczas naród "przywoła» wszystkich Litwinów do «jednoczenia się», może wtedy nie da się obejść bez udziału chrześcijańskich demokratów, ludowców, socjaldemokratów i wszystkich innych «kratów?»... Opłaca się głosić, że trzeba sprawę Wilna zawiesić" ${ }^{20}$.

A więc rozumowanie dość interesujące - „rząd narodowy” (reżim autorytatywny A. Smetony) nie może zmienić swego stanowiska w sprawie Wilna, nie może rozpocząć pertraktacji z Polską, bo wykorzystałyby to opozycyjne partie demokratyczne. Wypływał stąd wniosek, że władze smetonowskie nie rozpoczną rozmów.

Rządowy dziennik "Lietuvos aidas" twierdził nawet, że zagrożenie ze strony Niemiec nie jest aż tak wielkie, gdyż Trzecia Rzesza musi liczyć się z Polską, która we własnym interesie nie może pozwolić Niemcom na agresję przeciwko państwom bałtyckim, przede wszystkim przeciwko Litwie. Oczywiście położenie Litwy byłoby beznadziejne, gdyby Polska stała się rzeczywistym sojusznikiem Niemiec hitlerowskich. Lecz publicysta "Lietuvos aidas” uważał, że jest to niemożliwe, ponieważ: „Pomagając Niemcom w podboju Państw Bałtyckich, lub choćby samej Litwy, Polacy założyliby sobie sami pętlę na szyję. Każdy Polak jest tego świadom. Tak więc niemiecka ekspansja na Wschód przez korytarz polski jest z przyczyn strategicznych niemożliwa" 21 .

Wydawało się, że władze litewskie wierzyły, iż Polska nie pozwoli Niemcom na agresję na Litwę, chociażby w obronie własnych interesów, bez względu na stanowisko Litwy w sprawie Wilna i nawiązania stosunków dyplomatycznych.

W rzeczywistości jednak było inaczej. Wobec pogarszających się stosunków z Niemcami, rząd litewski zdecydował się szukać kompromisu w celu uregulowania sporu z Polską, nie wyrzekając się swoich roszczeń w kwestii Wilna i Wileńszczyzny. 18 marca 1934 roku w Ministerstwie Spraw Zagranicznych Litwy zaczęto rozważać plan przewidujący prowadzenia polityki

20 „Vairas” 1934, t. XI, nr 6, s. 227.

21 "Lietuvos aidas”, 15.V.1934, n r 109. 
przychylnej Polsce, jeśli Józef Piłsudski zgodzi się uznać sprawę Wilna za otwartą. Zrozumiałe jest, że nie pojawiły się w prasie litewskiej żadne informacje o takich planach.

2 stycznia 1935 roku na naradzie u prezydenta A. Smetony, w której uczestniczyli między innymi minister spraw zagranicznych Stanisław Lozoraitis oraz przedstawiciel dyplomatyczny Litwy we Francji P. Klimas, stwierdzono, że Litwie zagraża wielkie niebezpieczeństwo ze strony Niemiec i należy użyć wszystkich dostępnych środków politycznych, by się go ustrzec. Lozoraitis stanowczo opowiedział się za szukaniem porozumienia z Polską22.

Publiczne deklaracje o odrzuceniu propozycji zmiany litewskiej polityki wobec Polski nie odpowiadały realnym acz poufnym przedsięwzięciom rządu. W takich okolicznościach reżim nie był zainteresowany w uciszeniu dyskusji prasowej w sprawie Wilna, co mógł uczynić za pomocą stosowania surowszej cenzury. Przeciwnie można przypuszczać, że władze starały się temperować krytykę skierowaną przeciwko zwolennikom porozumienia z Polską. Dyskusję kontynuowano, ukazywały się artykuły bardzo przychylne Polsce, zwłaszcza w ocenie jej polityki i kultury.

W działaniach tych przodował już wspomniany tygodnik „Naujoji romuva" - niezależny, jednak czasami wspierany finansowo przez rząd. Na przykład jeszcze w maju 1934 roku tygodnik zamieścił korespondencję ze stolicy Łotwy, w której bardzo przychylnie oceniono wystawę współczesnej sztuki polskiej w Rydze. Pisano $z$ uznaniem o wspaniałej organizacji wystawy i jej wielkim sukcesie wśród publiczności łotewskiej ${ }^{23}$.

W sierpniu-październiku „Naujoji romuva” opublikowała cztery obszerne artykuły specjalnego korespondenta Władysława Jakubenasa: jego wrażenia $z$ podróży po zachodniej Polsce pod tytułem Listy $z$ „Kresów Zachodnich". W pierwszej korespondencji autor opowiadał swoje wrażenia ze Śląska, w drugiej - z Poznańskiego, w trzeciej oraz czwartej - z Gdyni i Pomorza ${ }^{24}$. Władysław Jakubenas $z$ uznaniem, a nawet $z$ zachwytem pisał o polskiej działalności narodowo-kulturalnej na terytorium byłego zaboru pruskiego, o pokonywaniu skutków germanizacji, o znacznym postępie gospodarczym, zwłaszcza w porównaniu z nędzą Wileńszczyzny, oraz o wspaniałym rozwoju portu w Gdyni.

22 A. Merkelis, Antanas Smetona, New York 1964, s. 485.

23 „Noujoji romuva” 1934, nr 174-175, s. 395.

24 „Naujoji romuva” 1934 , nr 188-189, s. $557-560 ; 1934$, nr 192, s. 612-615; 1934, nr 194, s. $656-657 ; 1934$, nr 199 , s. 775-777. 
O tych osiągnięciach zdecydowała, w mniemaniu Jakubenasa, polityka sanacji: „Polska jest typowym państwem wielkiej polityki. Władza jest w rękach silnych osobowości, które pewną ręką, nie zważając na środki, realizują swą linię..." 25. Taka ocena była doprawdy bardzo przychylną oceną władz państwa, z którym bądź co bądź Litwa odmawiała nawiązania oficjalnych stosunków, które uważała za wrogie.

W tymże tygodniku „Naujoji romuva" w październiku publicysta M. Būtautas wrócił do rozgorzałej w maju dyskusji. Kategorycznie odrzucił myśl Czepińskiego, że odzyskawszy Wilno „Litwa upadnie jako naród i jako państwo", gdyż po 15 latach niepodległości Republika Litewska wzmocniła się dostatecznie, by oprzeć się polonizacji. Jednocześnie M. Būtautas poparł ideę normalizacji stosunków z Polską, jeżeli zapewni to obronę przed zagrożeniem niemieckim. Zwrócił on jednak uwagę na drugą stronę problemu, przemilczaną przez wszystkich niemal litewskich polityków, działaczy społecznych i dziennikarzy: czy brak stosunków dyplomatycznych z Polską nie oddala Litwy od Wilna i nie szkodzi litewskiej mniejszości w Polsce. M. Būtautas pytał: „Czy litewskość na Wileńszczyźnie umacnia się, czy tylko utrzymuje swoje pozycje, a może ponosi klęskę? Jeśli ponosi klęskę, to być może uregulowanie stosunków z Polską, nie wyrzekając się przy tym Wilna, poprawiłoby sytuację na naszą korzyść. Przecież nam nie wszystko jedno, ilu będzie Litwinów na Wileńszczyźnie za dziesięć i więcej lat: czy naliczymy ich tam tylko setki, czy setki tysięcy, czy będziemy tam przez kogoś oczekiwani, czy już nikt nie będzie czekał" ${ }^{26}$.

Dla podtrzymywania więc na Wileńszczyźnie litewskości konieczna jest próba uporządkowania stosunków Litwy z Polską. Takie rozumowanie było całkowicie słuszne, lecz niezwykle rzadkie w publicystyce litewskiej. Po raz pierwszy podobny pogląd wyraził w 1932 roku E. Radzikauskas (pseudonim znanego litewskiego poety L. Giry) na lamach tygodnika "Naujas žodis" 27 . Lecz był to głos odosobniony, jakby wołający na puszczy, który wtedy nie doczekał się oddźwięku.

Publicysta „Naujoji romuva” podjął jeszcze jeden wątek sprawy wileńskiej, dotąd niespotykany w prasie litewskiej; nie mówiąc już o wypowiedziach działaczy politycznych, a mianowicie: czy nie należałoby nawiązać normalnych stosunków $z$ Polską, jeżeli ona zgodziłaby się zwrócić Litwie „te tereny pograniczne Wileńszczyzny, w których wyraźną więk-

\footnotetext{
25 „Noujoji romuva” 1934, nr 194, s. 657.

26 „Naujoji romuva” 1934, nr 196, s. 708.

27 „Naujas żodis” 1932, nr 15, s. 408.
} 
szość mieszkańców stanowią jeszcze nie wynarodowieni Litwini" 28. Co prawda, M. Būtautas zastrzegł się, że to tylko pytanie, na które nie podejmuje się odpowiedzieć. Ważne jest jednak, że w ten sposób wyrażona została wątpliwość $w$ dotychczas niepodważalne stanowisko władz i społeczeństwa litewskiego, iż Polska powinna oddać Litwie wszystkie tereny, przyznane jej przez Rosję Radziecką moskiewskim traktatem z 12 lipca 1920 roku.

Artykuł M. Būtautas'a nie wywołał takich kontrowersji jak wystąpienie A. Czepińskiego i L. Bistras'a. Władze oraz dziennik rządowy milczały. Tylko w tejże „Naujoji romuva” stały współpracownik tygodnika, socjolog, profesor F. Kemēšis zarzucił swojemu koledze naiwność polityczną i odrzucił jego stanowisko. F. Kemëšis uważał, że $z$ takim zaborczym sąsiadem jak Polska, która myśli o nowych podbojach, poważne traktaty są niemożliwe ${ }^{29}$. Wielce nierealistyczne było takie rozumowanie, nie odzwierciedlało ono prawdziwego, lecz nie wypowiadanego stanowiska rządu Republiki Litewskiej i znacznej części społeczeństwa.

Przedstawiciele rządu litewskiego kontynuowali nieoficjalne rozmowy z odpowiednimi osobistościami Polski. W prasie obu krajów pojawiły się liczne wzajemnie przychylne artykuły. Oczywiście, życzliwie oceniano osiągnięcia gospodarcze i kulturalne, a nie politykę w stosunku do mniejszości narodowych. Zwłaszcza że władze polskie od początku 1936 roku spotęgowały tzw. retorsje przeciwko litewskim stowarzyszeniom, szkołom i wydawnictwom na Wileńszczyźnie.

Pertraktacje nie dały rezultatów. Rząd polski w 1936 roku zgodził się nawiązać stosunki dyplomatyczne, gospodarcze i kulturalne oraz podpisać pakt o nieagresji z Litwą, jednocześnie formalnie nie sprzeciwiając się jednostronnej deklaracji Litwy, że nie rezygnuje ona ze swoich praw do Wileńszczyzny, lecz kategorycznie odrzucił propozycje pertraktacji w sprawie zmian terytorialnych. Natomiast władze Litwy nie zdecydowały się znormalizować stosunków z Polską na takich warunkach, chociaż (jak wykazała dyskusja z 1934 roku) tolerowały też zwolenników innych poglądów w tej sprawie i temperowały nadgorliwość ich przeciwników, aktywistów Związku Wyzwolenia Wilna oraz innych organizacji patriotycznych. Sytuacja międzynarodowa Litwy w obliczu zagrożenia niemieckiego stawała się coraz trudniejsza, a ostatecznie - beznadziejna. Ultimatum polskie wobec Litwy z 17 marca 1938 roku zmusiło rząd litewski do znormalizowania stosunków

28 „Naujoji romuva” 1934, nr 196, s. 708.

29 „Naujoji romuva” 1934, nr 199, s. 768. 
z sąsiednim państwem oficjalnie nie wyrzekając się pretensji do Wilna i Wileńszczyzny. Artykuł 6 nowej Konstytucji Republiki Litewskiej, przyjętej w maju 1938 roku, głosił, że stolicą państwa jest Wilno. Okazało się, że główny wątek rozumowania W. Czepińskiego, K. Pakštasa oraz L. Bistras'a był słuszny.

Przełożyli z litewskiego

Katarzyna Korzeniewska i Algis Kasperavičius 